\title{
THE THEOLOGY AND PRACTICE OF CHRIST APOSTOLIC CHURCH ON DIVINE HEALING IN THE CONTEXT OF PENTECOSTAL THEOLOGY
}

\author{
George O. Folarin \\ Department of Religious Studies \\ Obafemi Awolowo University, \\ Ile-Ife, Nigeria \\ gfolarin@oauife.edu.ng; folaringeorge@gmail.com \\ URL: http://ijourels.org.ng https://dx.doi.org/10.4314/ijrs.v7i1.2
}

\begin{abstract}
The motivation for this study emanated from review of literature which led this researcher to the realization that not much critical study has been done on the theology and practice of divine healing in Christ Apostolic Church (CAC). The CAC which is an important Pentecostal church in Nigeria traces its root partly to Precious Stone Society, a prayer group that began in South-western Nigeria in 1918. This article identified the tenet of faith of the church on divine healing; located the tenet of CAC in the context of the global Pentecostal theology and compared the initial understanding of the concept in CAC with the way it is perceived today by the church members. Primary sources of data for the work comprised the Bible, editions of CAC constitutions, articles written by founders of the Church, questionnaire, and interviews. Secondary sources of data comprised Bible commentaries, books, journal articles, and Internet sources. Historical and phenomenological approaches were adopted for the work. The study found that CAC initially held to divine healing without the use of drugs. It revealed that the belief of the Church on divine healing located the CAC at the center of Pentecostal theology which researchers have identified as healing. The study further discovered that the view of divine healing, with or without the use of drugs, held by the Church today has changed from the one held by the progenitors of the Church which was healing without the use of drugs. The work provides theological relevance on divine healing for the study of Pentecostalism in Nigeria.
\end{abstract}

Keywords: Divine healing, CAC, Use of drugs, Sanctified water, Anointing oil

\section{Introduction}

Many "royal battles" were fought by theologians and some other church leaders in the early part of church history before several doctrines were clarified. These theological clarifications were the outcome of the attempts to faithfully interpret the Scripture and summarize its teachings in the light of the church's experience of God. The clarifications became very necessary in the face of the onslaught of strange teachings which introduced confusion into the church and misled undiscerning church members.

Scholars have done some critical works on different aspects of CAC. For example, while Oshun focuses on a Pentecostal consideration of the historical, theological and organizational developments of $\mathrm{CAC},{ }^{1}$ Owoeye researches an 
influential CAC healing prophet, E.O. Babalola, of Osogbo. ${ }^{2}$ Alokan, on the other hand, works on the place of revelations and healings in $\mathrm{CAC},{ }^{3}$ Adedapo works on the healing ministry as a catalyst for the growth of $\mathrm{CAC},{ }^{4}$ Oluwaniyi works on the impact of miracles on the growth of $\mathrm{CAC},{ }^{5}$ and Akinsulure works on leadership in CAC. ${ }^{6}$ There has been little or no work on the critical study of the theology and practice of divine healing in CAC. This is the lacuna that the current research attempted to fill.

\section{The Tenet of CAC on Divine Healing}

The 12th tenet of CAC states that "We believe and hold: 'Divine healing through obedience to the command of our Lord Jesus Christ and faith in His name and merits of His blood for all sicknesses, diseases and infirmities."7 A tenet is an "[...] opinion, principle, dogma, belief, or doctrine, which a person holds or maintains as true." ${ }^{\circ}$ Because church tenets are at best human interpretations of divine truths, they may sometimes be wrong. This is particularly possible if the theological tenets are built on faulty exegeses and poor hermeneutics. ${ }^{9}$ Otten puts the issue thus, "[...] revealed truths are objectively permanent and immutable ... (but) their subjective apprehension and outward expression admits of progress."10 Morris therefore cautions, "[...] when ... tenets are taken to an extra-biblical extreme, or when modified by the assimilation of non-biblical nuances, the result is a distortion of orthodoxy."11 This is why church tenets need re-visiting, re-evaluating, and re-working at intervals to make sure that they are better conformed to objective interpretations of the Scripture. ${ }^{12}$ The term "tenets" is used in this article for CAC dogma or doctrines accepted by the Church to guide the religious practices of its members.

Of the constitutions of CAC $(1961,1970,1995 ; 1998)^{13}$ available to the current researcher only the edition of 1998 includes divine healing as a tenet. The claim of the late General Evangelist of CAC, Babajide, that, "[...] láti owọ́ Émí Mímọ ....ni a ti fi àwọn ilànà àti ẹkoọ ìjo CAC lé àwọn bàbá wa nínú ìgbàgbọ́ ... l'ọ́wọ́" (Translation: CAC practices and doctrines were handed down by the Holy Spirit to our founding fathers") is an overstatement. The current research showed in this article that CAC shares its tenet on divine healing with the Pentecostalism that existed before it. Some other tenets it holds in common with other Pentecostals are Baptism in the Holy Spirit with signs, government of the church by apostles; prophets, evangelists, pastors, teachers; and the nine gifts of the Holy Spirit for the edification of the church.

\section{Divine Healing: CAC in the Context of Pentecostal Scholarship}

Although belief in divine healing is common in CAC, the Church did not originate it. In fact, it is a doctrine common to all Pentecostal churches. Brown observes that divine healing is "an essential marker of Pentecostal and Charismatic Christianity as a global phenomenon."15 Some other scholars on Pentecostalism do agree with Brown ${ }^{16}$ that "divine healing" and not "[...] speaking in tongues or prosperity most characterises Pentecostalism as distinct 
from other forms of Christianity." 17 According to Cox, however, the fact that Pentecostals agree on the practice of divine healing does not imply "a singular theology of healing.", 18

Divine healing though has always been recognised and practised in Christianity, with the emergence of Pentecostalism, it became more emphasised. According to Synan,

While tongues came to the fore in 1901 and 1906 with the ministries of Charles Parham in Topeka, Kansas and William J. Seymour in the Azusa Street revival in Los Angeles in 1906, the emphasis on healing goes back to the mid-Nineteenth Century when efforts were made to restore New Testament signs and wonders to the church. ${ }^{19}$

In Europe, healing in answer to prayer was probably first taught by Edward Irving in London in 1830, Johann Christoph Blumhardt in Germany in 1843, and Dorothea Trudel in Switzerland in 1851. These men developed a "theology of healing which was to affect many in America and lead to the Pentecostal doctrine of divine healing 'as in the atonement'." ${ }^{20}$ The first person that popularized healing in America was Charles Cullis in 1870. "By the 1880's Cullis was conducting annual healing conventions in Old Orchard." ${ }^{21}$ It was however Adoniram J. Gordon that first included divine healing in the atonement of Christ, in his book published in $1882 .^{22}$ John Alexander Dowie, on the other hand, was the first person to divorce divine healing from medical treatment. He had "a strong antipathy to surgery and medicine" 23 and argued that medical doctors were agents of Satan. ${ }^{24}$ Synan comments on Dowie's ministry thus, "Dowie's stern position against all medicine and doctors ... took root in many sectors of the Holiness movement and became the majority view of the Pentecostals when the movement began in 1901 in Topeka, Kansas." ${ }^{25}$ This shows that divine healing without the use of drugs predated the emergence of modern Pentecostalism, and was inherited from earlier holiness movements, and was made popular by early Pentecostal movements. ${ }^{26}$

Literature on divine healing without the use of drugs was produced in abundance and distributed widely following the influenza epidemic that broke out after the World War I (1914-1918). ${ }^{27}$ From that time on many Holiness and Pentecostal churches began to canvass for complete reliance on the power of God to the exclusion of the use of medicine to heal the epidemic and other sicknesses in the Western world. It was around this time that the Western part of Nigeria experienced a similar epidemic against which Western medicine was generally ineffective. This was also the time when the prayer group that later became known as the Precious Stone Society emerged. Its emergence provided an effective response to the epidemic. ${ }^{28}$

Both Charles Parham and William J. Seymour, regarded as fathers of modern day Pentecostalism, held to divine healing without the use of drugs. ${ }^{29}$ As at 1906, "The Apostolic Faith" church had started to teach that there were three blessings in atonement. The church identified these blessings as forgiveness of 
sin, sanctification, and healing of human bodies. ${ }^{30}$ But from the time the World War II ended, the wind of change began to blow among the Pentecostals in the West on re-defining the concept of divine healing to include use of medicine.

According to Kydd, two major healing models developed after the emergence of Pentecostalism. The first is called "Revelational model" (1907). The model is described thus,

Practitioners of the revelational approach came to expect that God would give them special knowledge. He would show them what needs were present or who was being healed ... God reveals information upon which the healer can act. ${ }^{31}$

Kathryn Johanna Kuhlman (1907-1976) is an example of this model. She started healing ministry in 1947 and her ministry became popular almost immediately it started. She became a leading proponent of healing evangelism in the 1960s. She explained that she had nothing to do with the healings in her ministry. She insisted that "God performs the miracles according to his purposes and plans about what she knew absolutely nothing. The Holy Spirit revealed to her only what God had done." 32

The second is called "Soteriological model." This model states that Christ has paid for Christians' healing through his atoning work. According to Kydd, this model locates "... the attack on illness within the doctrine of salvation (soteriology)." ${ }^{\prime 33}$ One of the model's most able proponents is Granville Oral Roberts (1918-2009). ${ }^{34}$ His healing ministry began to be popular from 1947 . Oral Roberts' theology of healing built and then improved on the theology of healing that existed before his time. Taking over the theology that healing is in the atonement of Christ, Oral Roberts added two more important poles to the theology of healing. The two added poles are called "certainty" and "sovereignty" by Kydd. Oral Roberts is quoted as expanding the concept of divine healing to be, "more than spiritual, more than mental, more than physical - it is that and more." " To Oral Roberts, the first pole called certainty is the state of the mind of the patient where the sick is convinced that God is able and willing to heal "now." The second pole, sovereignty, though painful and disappointing to Oral Roberts, refers to the prerogative of God to decide who, at the end of the day, is healed. Jennifer Anne Cox recently makes a similar observation with Oral Roberts, "Why particular people are not healed is a mystery of God's sovereignty." 36 This soteriological approach to healing has arguably influenced many modern day Pentecostal approaches to healing. Again, Oral Roberts was the first Pentecostal that uniquely combined faith healing with use of drugs in his Oral Roberts University Hospital in Tulsa. The hospital was designed to merge prayer and medicine in the healing process and the project succeeded in doing that for some time before it suffered financial crunch. The approach has greatly influenced many Pentecostals to view prayer and medicine as partners in the process of divine healing. 


\section{The Practice of Divine Healing in CAC}

In Nigeria, the Precious Stone prayer group was formed in $1918 .{ }^{37}$ In that year, a school teacher in an Anglican school near Ijebu Ode, Sophia Odunlami, claimed to receive a divine call as a prophetess. ${ }^{38}$ While myth and reality are difficult to separate in stories about her, nearly all scholars who ventured to conduct research on her concluded that her ministry against the ravaging epidemic was effective and that her calling was genuine. ${ }^{39}$ Odunlami emphasized the power of God to heal. She introduced three things to the concept of healing which have continued, how-be-it in modified forms, in CAC till date. The first was condemning Òògùn síse (making medicine) and Òògùn lílò (using medicine) because nwón lódì sí ifé Olórun (they are against the will of God). ${ }^{40}$ Her concern in the prophecy thus appears to be with Christians relapsing into traditional religious remedies for healing of the ravaging epidemic that defied Western medicine rather than totally forbidding use of medicine. This interpretation tends to agree with Orogun's explanation to the CAC Sunday School workers in Ilorin in 1982 that the early progenitors of CAC forbid the use of medicine at that time because available hospitals were few and they were often far from the people. Other reasons, according to Orogun were that Western medicines were not effective for the epidemic, and it was difficult to distinguish the herbs and concoctions upon which demonic spirits were conjured from those upon which incantations were not pronounced. ${ }^{41}$ Again, Odunlami delivered another oracle to her audience that they should use rain water and, blanched oil sanctified with prayer for healing. ${ }^{42}$

Folarin, Oladosu and Baba are of the view that Odunlami's recommendation that rain water be blessed and used in the cure of the 1918's is an important background to the practice of using sanctified water in CAC. They argue further that Joseph Babalola's use of blessed water for healing further popularised its use as a "means" of healing in the church. It is noteworthy also that the church's leadership at no time officially approved or disapproved the use of water for healing in the church. ${ }^{43}$ While the use of water for healing is entrenched in the culture of the Yoruba people of the Western Nigeria, water was also a means of healing in the Bible. ${ }^{44}$ The use of water for healing thus resonates well with the African and every attempt to discourage its use in prayer by some well-meaning members of the prayer group failed. Again, the use of blanched palm oil in praying for the sick later encouraged the use of olive oil in healing prayer especially among CAC prophets.

Healing with the use of sanctified water assumed a new dimension in Joseph Ayo Babalola's ministry. Ogunrinade holds that the use of water for healing began with "the encounter that Prophet Ayo Babalola had in 1928 when he saw Christ in a revelation giving him a bottle of water and telling him to drink." ${ }^{25}$ While many writers acknowledge that Babalola used sanctified water copiously for healing throughout his ministry, not all of them agree that he initiated it use. For example, Babalola used blessed water in Omu-Aran to deliver 
a woman of her four-year delayed pregnancy. ${ }^{46}$ There are other prophets of CAC who used sanctified water for healing. Daniel Orekoya was one of them. ${ }^{47}$

Some other healer-prophets in CAC were David Olulana Babajide, Samson Oladeji Akande, Timothy Oluwole Obadare, Godwin Nwoye, Patrick Abu Ayewo Egabor, and Ezekiel Olatidoye Babalola. Evangelist D.O. Babajide became the second General Evangelist of CAC after the transition of Joseph Babalola. Extensive use of blessed water for healing in the $\operatorname{church}^{48}$ has been documented by Folarin, Oladosu and Baba (CAC Oke Itura, Akure), ${ }^{49}$ Adewale (CAC Agbala Itura, Ibadan), ${ }^{50}$ and on CAC prayer mountains (Oke Aanu in Erio Ekiti, Ori Oke Ajinare in Ido-Ile, Ori Oke Babalola in Odo Owa and, Ori Oke Ikoyi near Ikire $)^{51}$ among others by Shittu. There is a sort of continuity in the use of water for healing in the traditional African religion and the CAC. The informed members of the Church realise that God is ultimately the healer and not the water.

Ezekiel Olatidoye Babalola, also known as "Baba Agric" was an influential CAC healing prophet. The base of his ministry was Osogbo in Osun State, Nigeria. In the $1980 \mathrm{~s}$, he healed a boy, Lukman, who had no mouth opening was sealing up when operated upon by medical doctors. The boy was later taken to Baba Agric who "... prayed and applied olive oil on the mouth and the mouth opening remains permanent till date." 52 According to Owoeye, Baba Agric used to heal through "hydrotherapeutic" method. ${ }^{53}$ In an interactive discussion on the ministry of Baba Agric, Gbadegesin disclosed he witnessed the prophet healing the sick by means of prayer and with the use of anointing oil and blessed water..$^{4}$

Prophet Timothy Oluwole Obadare was another great prophet-healer of CAC. He used water and anointing for healing in his crusades and church programs. God allegedly instructed him to dig a well for healing in 1969 and, he obeyed. ${ }^{55}$ Some CAC members do cite Bible texts, such as 2 Kings 5:1-19 on the healing of Namaan and John 9:1-11 on the healing of a blind man In the two cases, water was used as a means of healing. Water, after been sanctified with prayer for miracle becomes what Yoruba people call, Omi ìye, that is, "water of life" or, "water that brings life." This term adequately captures the idea behind water as a divine means of conveying life to all forms of numbness caused by sickness, demons, poverty, or/and insecurity.

In CAC like in other African indigenous churches, Omi iyè is used for bathing, drinking, washing, and sprinkling. Such water is sometimes blessed in private, sanctified for them by pastors/evangelists in church services, on revival grounds or on mountains or in prayer camps, etc. Akinsulure recently observes, "[...] this practice is gradually fading away in many of CAC assemblies in towns and cities, [but]it is still very much in vogue in the rural areas and, in prophets' churches." ${ }^{\circ 6}$ But for too long, CAC has officially ignored the practice of using sanctified water for healing without making any official policy on it probably because those who employ it do claim prophetic authorization ${ }^{57}$ From hindsight, it is clear that Ademakinwa's expectation that "...these things would end ... 
[w] hen we ... [have] a better understanding of the word," has remained elusive as he acknowledges later, "some people brought them back.", 58

Both Ogunwole and Alokan have ventured into CAC's use of fasting and prayer, blessed water, and hand bell for healing in their research works. ${ }^{59}$ The two researchers also note that CAC uses church hand bell while praying for healing. Joseph Ayo Babalola was credited with introducing the use of hand bell in prayer to the church. ${ }^{60}$ This rod was compared with the rod of Moses in Exodus 4:1-4; and Elisha and Gehazi in 2 Kings 4:29. Babalola claimed that the use of the rod was to shatter evil forces and set free those who were held captive by demonic forces. ${ }^{61}$ Although CAC adherents respect Babalola's prophecies, most CAC members shun the practise of using prayer staff and the practice gradually died out. One Isaac O. Olanrewaju, a former Provost of CAC Theological Seminary, Ile-Ife, briefly re-introduced the use of prayer staff to the church which embarrassed many church leaders and followers of CAC. If some prophets/prophetesses in CAC still use prayer staff today, then they are insignificant in number and the practice is dying out. This is one instance where Babalola's vision was silently rejected.

The practice of divine healing among the founding fathers and mothers of CAC predated the merger of the Precious Stone Society with the Faith Tabernacle Church of Philadelphia. At the end of World War I (1914-1918), in 1918 to be precise, a terrible epidemic broke out globally and the southern part of Nigeria was seriously affected. The epidemic killed many people particularly in the southern part of Nigeria and many public institutions and churches were closed down. Many professing Christians returned to traditional religion for cure. ${ }^{62}$ The cause of this backslide was the belief of Africans that incurable sicknesses are caused by malevolent spirits and that no medicine could cure those infected by such sicknesses. The Yoruba name for these spirits is Ajogun. Gbadegesin defines Ajogun as "forces of evil which afflict unprotected human beings." 63 The Ajogun are believed to cooperate with witches ${ }^{64}$ to cause human beings misfortune and calamity. When they are responsible for any misfortune, it is believed that such can only be assuaged by appeasing them with sacrifice or by fighting them by means of a more superior power which the Christians believe that is available in Christ Jesus. Christ Apostolic Church members, with their belief that all forms of problems including sicknesses are caused by evil spirits, ${ }^{65}$ therefore hold that medicine should not be used to cure sicknesses. The logic here is that if the sicknesses were caused by demonic forces, injection or any other medicine would not be able to cure them. This could explain why in the 1918 episode, those who had not gone back to the traditional religion for help to cope with the epidemic were told to depend wholly on God since medicine was ineffective in the situation. It is in this same light that Babalola's reason for discouraging the use of medicine is reasonable: because the effect of drug is limited. It was at that critical point in the life of the church that some members of St. Saviours (CMS) Church in Ijebu Ode formed a prayer group for divine intervention. Since the Anglican Church in Ijebu Ode had been shut in 
conformity with the advice of the then Colonial administration, the group members gathered for regular prayer in front of the church. The prayer group was led by one Joseph Shadare.

As testimonies of divine healing in answer to prayer of the group began to increase, more people joined the group. ${ }^{66} \mathrm{CAC}$ later inherited and improved on the group's practice of divine healing. The situation that led to Odunlami's prophecy against the use of Ògùn is adequately captured by Aiyegboyin and Ishola when they explain that the epidemic led some people "to put the Christian religion behind them and ... go back to the traditional religion. ${ }^{67}$ Her prophecy in that context was therefore primarily to discourage afflicted Christians from returning to traditional religion with its medicine for solution to the perplexing epidemic. The group then added abstinence of orthodox medicine to its meaning of divine healing and that abandonment contributed in a major way to the final split of the prayer group from the Anglican Church. At last, the group was expelled from the Anglican Church in 1922 because it held to healing without the use of medicine, emphasised dream and vision as means of accessing divine revelation, and opposed child baptism. Ogunleye adds "abstinence from dancing, drumming, drinking of alcohol, gambling and mixing with non-Christians" to the things that led the Anglican Church to expel the prayer group. ${ }^{68}$

The second part of Odunlami's prophecy regarding ògùn lílò (Translation: use of medicine) forbids the use of orthodox medicine without giving reasons for the sanction. The rejection of the use of orthodox medicine could, however, be due to the ineffectiveness of the medicines against the epidemic devastating the community at the time. It is therefore not certain that Odunlami intended to permanently forbid the use of orthodox medicine by Christians. The reason for Odunlami's prohibition could be similar to the one which an angelic messenger gave to Joseph Babalola on why he should discourage the use of medicine for healing: because "medicine... provide(s) only temporary solution ..." to the people's problems. ${ }^{69}$ Locating this prohibition in the context of what was happening among other Pentecostals in other parts of the world one discovers that they too held that the use of medicine by Christians was a $\sin ^{70}$

In Curtis's review of J.W. Williams' book on Spirit Cure: a History of Pentecostal Healing, the reviewer notes that it was only after the Second World War that "most Pentecostals abandoned their initial hostility toward the medical profession and the use of 'means' in the healing process." 71 This implies that as at the time The Precious Stone Society emerged, most Pentecostal groups globally regarded use of medicine as wrong. Unlike the Pentecostals in the West however, neither the Precious Stone Society nor the CAC in later years ever designated the use of medicine as a sin. The closest the church pronounced on this was that believers in Christ were not taught to consult doctors or use medicine in sickness and pregnant women were disallowed from visiting hospitals for check-up or child-birth. ${ }^{72}$ 
Truly, some members of the church interpret visits to doctors and use of drugs as sinful but there is nowhere the church officially designates it so. Some members hold their prohibition from visiting medical doctors as the church's official pronouncement of the use of drugs as a sin. The view that the use of drugs for healing was a sin was however introduced to the Nigerian church by the Faith Tabernacle Church of Philadelphia. Today, nearly all if not most of CAC Faith Homes, that is CAC Maternity Homes, have medical doctors as consultants. There is a working relationship between them and hospitals to which stubborn cases are referred whenever the needs arise. Likewise, cases suspected of demonic involvement are sent to CAC Faith Homes or CAC prophets as necessary in a symbiotic relationship. One of the things certain today is that CAC like other Pentecostal churches still holds tenaciously that God is ultimately the healer. Another is that if God is sovereign in all issues as CAC believes then he may heal through the use of medicine, water, or anointing oil, he can heal all the sick brought to him at any particular time, and he can decide not to heal anyone at any given time. One vital factor in the healing ministry of the CAC is the need for constant prayer and fasting. ${ }^{73}$ This is supported with Jesus' statement in Mark 9:29, "This kind cannot come out by anything but prayer.",

Like Odunlami, Joseph Babalola also claimed to have been directed divinely to use blanched oil for healing. Ojo explains that "He was ... under instruction to bless fried palm oil for the anointing of the sick ...."75 The use of blanched oil by Odunlami and Babalola is comparable to the use of anointing oil for healing in James 5:14, "Is anyone among you sick? Let him call for the elders of the church, and let them pray over him, anointing him with oil in the name of the Lord" (ESV). Again while Sophia Odunlami introduced the use of "anointing oil" for healing to the Precious Stone Society, Babalola consolidated and popularised its use among the church's prophets in CAC. It is used in the contemporary times profusely in prayer centres (e.g., Efon Alaye), on prayer mountains (e.g., Ori Oke Ikoyi), ${ }^{76}$ in church assemblies (e.g., CAC Agbala Itura, Ibadan) ${ }^{77}$ and in revival programmes. Recently, the use of anointing oil has been expanded beyond healing. Resulting from influences of neo-Pentecostal churches, the use of anointing oil for break-through, promotion, prosperity etc., is now common in CAC. Persons, cars and bicycles, biros, houses, tools among other things are being anointed ${ }^{78}$ contrary to the practice of the founding fathers and mothers of CAC. The fear now is that not sanctified water only but anointing oil also are being abused in the church. These "means of grace" are now being used magically as if they possess power in themselves to heal.

Despite the fact that the use of anointing oil for healing especially by prophets is widely accepted in the church, that use has no official approval. It is only allowed for healing by the CAC because certain respected prophets claim that they were told to use it thus by God. The use of olive oil for ordination of church ministers is the only one that is officially endorsed. It is stated in the church's order of service for the ordination of Pastors thus, "[...] we anoint you now with oil and separate you today for the work of a Pastor in Christ Apostolic 
Church, in the name of the Father and of the Son and of the Holy Spirit." same endorsement is given to the use of olive oil in the ordination of Evangelists. ${ }^{80}$

The articles in the book, Letter Mimo Si o, are representative of articles and sermons of the elites among the founding father and mothers of CAC. Failure to properly discern the primary focus of Babalola and the CAC at large has led many contemporary ministers in the church to shift their emphases. Folarin discovers in a research carried out in 2005 that CAC has largely shifted uncomfortably from emphasising the salvific issues which the founding fathers and mothers of the church were known for to therapeutic issues. ${ }^{81}$ This was not caused just by the socio-economic depression plaguing Africa but also by the inability of the church prophets and pastors to clearly recognize the primary from the secondary emphases of the gospel message.

The CAC's interpretation of Odunlami's vision on the use of medicine for healing as a sin was most likely an influence of the Faith Tabernacle Church of Philadelphia. "The Precious Stone Society" was exposed to the teachings of the Faith Tabernacle Church on the use of drugs through D.O. Odubanjo who had access to the church's magazine. ${ }^{82}$ Adegboyega succinctly explains " [...] we were not using the Bible as we used the Sword of the Spirit .... We can safely and boldly say ... today in matters of faith in divine healing ... [we] depend largely on the inspirational teachings inherited from Faith Tabernacle Congregation and which had been attested to by our experiences in the past. ${ }^{83}$

The Faith Tabernacle Church in Philadelphia holds till date that the use of medicine for healing is a $\sin ^{84}$ and so the interpretation of divine healing as without the use of drugs by the Precious Stone Society was likely an influence from the Faith Tabernacle Congregation in Philadelphia. If so, then divine healing without the use of drugs located the Nigerian group at the centre of Pentecostalism at the time. Therefore while the interpretation of the doctrine of healing without the use of drugs was unquestionably accepted by the Precious Stone Society because it agreed with the encounter of its founding members, the society did not originate the belief.

In 1930 there was still contention among the members of Faith Tabernacle Congregation in Nigeria on the rightness or otherwise of the use of drugs for healing. A meeting was called for 9 and 10 July in Ilesa to discuss the report sent to the leaders of the church on one Pastor J.A. Babatope accused of teaching the church in Oyan that the use of drugs, local or foreign, is right, the view which was contrary to that held by majority of the church members. ${ }^{85}$

The miracle of raising the dead by Joseph Babalola in Ilesa led to a twist on an important agenda that the meeting was planned for. The leaders of the new church met to debate the rightness or wrongness of Christians using drugs for healing when Babalola suddenly raised a dead man. The leaders of the church concluded from this event that God disapproves of the use of drugs for healing. In that meeting, no decision was adopted, but those who were canvassing that divine healing should be understood to also include the use of drugs temporarily 
suffered a setback. Orogun admits this fact about 50 years later when he writes, Kòtí tó àdọta odún (50 years) tí a bẹrè tí a sì wa da bayi. İjọ wa wá di İjọ ológun, èrò Hospital ("It is not yet 50 years that we established our church that we have turned to this. Our church has become a drug using one, our members patients of hospital"). ${ }^{86}$

Adedapo summarises what finally led CAC to accept the use of drugs for healing is succinct. First is the change of leadership brought to the CAC Maternity Training Centre in Ede by the CAC authorities in 1958. When Mrs Oladiran who was a nurse trained in orthodox medicine in London was made the head of the Faith Home in Ede (i.e., where church midwives were trained) there began a "shift in paradigm" in divine healing in CAC. Because of many complications which resulted from deaths in the CAC Faith Homes, "[...] litigations and rancour that normally ensue[d] from incidences of mismanagement of health matters with regards to the handling of delivery and sicknesses" the church leaders saw it necessary to make a trained nurse from the West to head the church's midwifery training home. ${ }^{87}$ Second is what Adeleke writes, quoting E.H.L. Oluseye that Joseph Ayo Babalola did not forbid anyone from using orthodox medicine for healthcare. ${ }^{88}$ This second point is questionable as the writings of Joseph Babalola suggest otherwise. Third is that the sanctified waters used in healing were bastardised by some of questionable moral behaviour. According to Adedapo "[...] some leaders ... [began to sell] miracle waters, exploiting the people and, enriching their pockets from ... [it]." ${ }^{, 89}$ This practice allegedly discouraged several members of CAC from the practice of healing without the use of drugs. The fourth is that many people are of the view that healing through prayer takes longer time than in medical homes. The fifth is that many members of CAC are well read and as such are critical of what they do. Many things that were initially regarded as demonic now have convincing scientific explanations and in many cases, technology has simplified healthcare delivery. So some issues which many in those days would run to the church for no longer command such reaction. Today, many see the need for healing without the use of drugs only when they are absolutely certain that it has demonic involvement.

Reading through the writings of its early leaders, one discovers that the understanding of most members of the Precious Stone Society and the Faith Tabernacle Congregation was that the use of drugs by Christians was wrong. Early after the founding of CAC, the church stipulated that a pregnant woman "[...] shall not go to any hospital/maternity home either for check-up or childbirth." $" 90$ The constitution attached a stiff sanction for the violators of the regulation: the offenders would be suspended from participating in the sacrament of Holy Communion for six months. ${ }^{91}$ This is just a step from designating Western Medicare a sin. ${ }^{92}$ The constitution also addresses other church members when it states that any church member who "denies divine healing" by visiting or/and dying in the hospital would not be buried by the church. ${ }^{93}$ Two reasons are given for this: the first is based on myriads of Bible passages such as Genesis 20: 
17-18; 2 Chronicles 16:12-13; 2 Kings 1:2-4; Psalm 107:17-20; Mark 16:17-18; James 514-15 etc.

Babalola contends that sickness is a punishment for sin and that with the forgiveness available in Christ's atonement, sin and sicknesses would be removed from the lives of the Christians who claim the benefit. ${ }^{94}$ With this Joseph Babalola supports the view common among the Pentecostals that there is healing in the atonement. Arguing this furthermore, Babalola points out that a Christian who benefits from the healing in Christ is to in turn become a healer of others. ${ }^{95}$ In one of his comments, Babalola states, Olúwa "fihàn mí gbangba pé ònà oogun șíse kí ise eyi ti enia le rin de odo Oun, nítorípé ònà tito Olọ́run míràn léhin ni" (The Lord "showed me clearly that the way of 'doing medicine' is not the one a person can take to him because it is the way of following another god"). ${ }^{96}$ It would be remembered that Odunlami had earlier used the same term, "ògùn șíse" (doing traditional medicine) as Joseph Babalola here uses it. It is possible that the two of them use the term for the same thing, consulting traditional religious priests for cure. While the purpose of Joseph Babalola in his article intends to discourage the use of drugs for healing, if he had wanted to forbid the use of drugs, a better term to use in Yoruba would have been "ogun lilo" (using medicine) not "ogun sise" (producing medicine). In a reported prophecy of Joseph Babalola, Ojo writes,

$[T]$ here are three things that spoil or destroy a church .... They are (i) the snatching of women from their rightful husbands in the church; (ii) borrowing or embezzlement of money from the church coffers; (iii) the use of charms or patronage of herbalists by church members. ${ }^{97}$

If Ojo's record above is correct, then while Babalola did not promote the use of orthodox drugs, his crusade was really against the use of traditional/cultic medicines and the entrapment they pose to Christianity.

Orogun argues that CAC was founded on three things: faith in God alone for healing without the use of drugs; faith alone in Christ for salvation without depending on human work; and dependence on God alone for material provision without borrowing from others. ${ }^{98} \mathrm{He}$ notes that CAC differs from other denominations in its emphases on divine healing and Holy Spirit. ${ }^{99}$ These two claims of his are not correct because belief in divine and baptism of the Holy Spirit are common to all Pentecostal churches. Although more daring in his approach than Joseph Babalola but along the same line, Orogun argues that the use of drugs for healing in CAC is "a great sin, a disobedience to Jesus and a rejection of Jesus." 100 Yet his argument in the article does not support his conclusion. Like several others of Orogun's persuasion, sickness is presented as exclusively resulting from the patient's sin and that repentance from sin ultimately leads to healing. Orogun's argument is obviously simplistic and only partially true to human experience. The argument wrongly assumes that the righteous are never sick and that good health is the evidence of divine approval. Clearly, some but not all sicknesses are caused by sin and true repentance in 
cases caused by sin can lead to forgiveness and healing. There are however other sicknesses that are caused by ignorance, infection, pollution, over-work, old age, etc. There are many innocent people whose sicknesses result from other's errors or wickedness. There are also sicknesses caused by demonic attack. Alokan's summary statement on CAC's position on the use of medicine is more cautious and salutary, "... the CAC [only] largely forbids the use of medicine in any form."101

A field study was carried out to identify CAC members' understanding of the belief and practice of the founding progenitors of the church and the view held by the contemporary members of the church. The results of the field investigation are presented below.

Table: Analysis of Responses on Divine Healing

\begin{tabular}{|c|c|c|c|c|c|c|}
\hline \multirow{3}{*}{ Item } & \multicolumn{6}{|c|}{ Responses } \\
\hline & \multicolumn{2}{|c|}{ North } & \multicolumn{2}{|c|}{ Southwest } & \multicolumn{2}{|c|}{ Total } \\
\hline & $\mathrm{n}$ & $\%$ & $\mathrm{n}$ & $\%$ & $\mathrm{n}$ & $\%$ \\
\hline \multicolumn{7}{|l|}{$\begin{array}{l}\text { 1. God's ability to heal without the use of } \\
\text { drugs }\end{array}$} \\
\hline $\begin{array}{l}\text { a. God can and does heal in CAC without } \\
\text { the use of drugs }\end{array}$ & 110 & 98.2 & 267 & 98.5 & 377 & 98.4 \\
\hline $\begin{array}{l}\text { b. God can but refuses to heal in CAC } \\
\text { without the use of drugs }\end{array}$ & 01 & 0.9 & 03 & 1.1 & 04 & 1.1 \\
\hline c. No response & 01 & 0.9 & 01 & 0.4 & 02 & 0.5 \\
\hline Sub Total & 112 & 100 & 271 & 100 & 383 & 100 \\
\hline \multicolumn{7}{|l|}{ 2. $\frac{\text { CAC discourages the use of drugs for }}{\text { healing }}$} \\
\hline $\begin{array}{l}\text { a. Church members were told not to use } \\
\text { drugs when sick }\end{array}$ & 65 & 58.0 & 174 & 64.2 & 239 & 62.4 \\
\hline $\begin{array}{l}\text { b. Church members were not discouraged } \\
\text { from using drugs when sick }\end{array}$ & 42 & 37.5 & 82 & 30.3 & 124 & 32.4 \\
\hline c. No response & 05 & 4.5 & 15 & 5.5 & 20 & 5.2 \\
\hline Sub Total & 112 & 100 & 271 & 100 & 383 & 100 \\
\hline $\begin{array}{l}\text { 3. Use of drugs was viewed as a sin } \\
\text { a. Yes, the church viewed the use of drugs } \\
\text { as sin }\end{array}$ & 77 & 68.8 & 120 & 44.3 & 197 & 51.4 \\
\hline $\begin{array}{l}\text { b. No, the church did not view the use of } \\
\text { drugs as sin }\end{array}$ & 26 & 23.2 & 137 & 50.5 & 163 & 42.6 \\
\hline c. No response & 09 & 8.0 & 14 & 5.2 & 23 & 6.0 \\
\hline Sub Total & 112 & 100 & 271 & 100 & 383 & 100 \\
\hline \multicolumn{7}{|l|}{$\begin{array}{l}\text { 4. Personal opinion of respondents on the } \\
\text { use of drugs }\end{array}$} \\
\hline $\begin{array}{l}\text { a. It is not wrong to use drugs when one is } \\
\text { sick }\end{array}$ & 56 & 50 & 160 & 59.1 & 216 & 56.4 \\
\hline $\begin{array}{l}\text { b. It is wrong for a Christian to use drugs } \\
\text { when sick }\end{array}$ & 42 & 37.5 & 99 & 36.5 & 141 & 36.8 \\
\hline c. No response & 14 & 12.5 & 12 & 4.4 & 26 & 6.8 \\
\hline Sub Total & 112 & 100 & 271 & 100 & 383 & 100 \\
\hline
\end{tabular}

Source: Data gathered by George O. Folarin in 2017 
Item 1 on the table reveals that almost every church member understands the view of CAC founding fathers and mothers to be that God did heal and continues to heal without drugs in CAC. From the Northern region, 98.2\% ( $\mathrm{n}=$ $110)$ and South-western region, $98.8 \%(\mathrm{n}=170)$ people affirmed this position. With the total of $280(\%=98.6)$ people affirming the position, the view of only two $(\%=0.7)$ respondents who disagreed with that position is hereby regarded as insignificant. The view of the remaining two $(\%=0.7)$ respondents who volunteered no response is qualitative and is therefore not considered. Item 2 on the table shows that 65 of $112(\%=58.0)$ of the respondents from the Northern region and 112 of $172(\%=65.1)$ from the South-western region remembered vividly that $\mathrm{CAC}$ used to discourage the taking of drugs for treating sick church members. In all, $177(\%=62.3)$ of the 284 agreed that that was the position of the CAC in those days as against the view of 42 of $112(\%=37.5)$ respondents from the Northern region and 48 of $172(\%=27.9)$ from the South-western region. The view of the 17 of $284(\%=6.0)$ that gave no response is qualitative rather than quantitative and so is not reckoned with. Finally, Item 3 on the table shows that opinions are slightly divided on if CAC traditionally viewed the use of drugs for the healing of members as a sin or not. While most respondents from the Northern region ( 77 of $112=68.8 \%$; cf. 26 of $112=23.2 \%$ ) were of the view that the church used to view the use of drugs for healing by members as a sin, respondents from the South-western region $(79$ of $172=45.9 \%$; cf. 81 of $172=$ $47.1 \%$ ) disagreed that that was the belief. The addition of the views from the two regions however, shows that while 156 of 284 (54.9\%) agreed that the church traditionally regarded the use of drugs for healing as a sin, only $107(37.7 \%)$ of the 284 respondents disagreed with the view. The view of the remaining 21 of $284(7.4 \%)$ respondents that volunteered no answer was discarded.

Item 4 on the table on the contemporary view of CAC members on the use of drugs for healing indicate that majority of them no longer view the use of drugs for healing as wrong. Responses from the Northern region 56 of $112(50 \%)$ and South-western region 115 of $172(66.9 \%)$ show that majority of the contemporary members of CAC do not see the use of drugs for healing by members as wrong. From the Northern region, 42 of $112(37.5 \%)$ and from the South-western region 46 of 172 (26.7\%) respondents still see the use of drugs for healing by church members as wrong. When the responses are totalled, it is discovered that majority of CAC members 171 of $284(60.2 \%)$ as against 88 (31.9\%) no longer view the use of drugs as wrong.

In sum, field study on the view held by the founding fathers and mothers of CAC reveal the followings. First, that church members believed and practised divine healing without the use of drugs. Second, that the church discouraged members from using drugs whenever they were sick and, third, that the use of drugs for healing was largely regarded by the church as a sin although there is significant dissention of opinion to this view. The research also found out that the view of the contemporary members of CAC is that the use of drugs by church members for healing is not a sin. A logical conclusion from the findings above is 
that while CAC members today do believe that God does heal without the use of drugs, he can as well heal with the use of drugs. He may also decide to heal with the use of sanctified water, blessed oil, or medicine. The important thing is that God is ultimately the healer of his own and is sovereign in the approach he takes. Pentecostals all over the world involve God in their healing theology: "For by his stripes you were healed!" (Is 53:5 cf. 1 Pet 2:25). From sober reflection however comes the realisation that nearly all God's generals finally succumb to one form of sickness or the other before they die. Samson O. Akande and Timothy O. Obadare died with blindness. Daniel Orekoya died of skin burn caused by a gaslamp explosion. ${ }^{102}$ J.A. Babalola had his sore. I.B. Akinyele was briefly sick before his death. Like Paul who learned to live with his thorn, God's saints are not deterred by temporal pains which God may decide to remove or allow in the exercise of his sovereign will. They do say with Paul, "Who shall separate us from the love of Christ? Shall trouble or hardship or persecution or famine or nakedness or danger or sword?" (Rom 8:35).

\section{Conclusion}

The $12^{\text {th }}$ tenet of CAC on divine healing which states that the church believes, "[in] obedience to the command of our Lord Jesus Christ and faith in His name and merits of His blood for all sickness, disease and infirmities," vague and burdensome. It is vague because it can take the meaning of healing with or without the use of drugs as long as God is acknowledged as the ultimate healer. It is burdensome because it places the burden of having faith for healing on the sick that is already overburdened. The followings are important to constructing a balanced theology of healing in Pentecostal churches, CAC inclusive. First, while healing is an important focus of Pentecostalism, it should be put in its proper place and not made to take priority over repentance and salvation from sin. Second, God's sovereignty should not be compromised even while encouraging healing, for it is not true that God wants to heal all the sick at all times. Third, whenever Pentecostal theology heightens the condemnation of the poor and he sick, such theology needs be questioned. The observation of Cox is frightening that Pentecostal churches do not welcome the disabled in their midst because they are regarded as demonstrating the failure of the Pentecostal theology of total deliverance from sickness.

Attempt was made in this article to subject CAC interpretation of divine healing to critical study with the aim of promoting objective study of Pentecostal practices in Nigeria. The study exposed the apparent propagandist interpretation of the tenet of divine healing in the church. The discovery is not unique to CAC. The findings can be duplicated in the interpretations of divine healing in some other Pentecostal churches at least in Nigeria. Pentecostal churches are therefore challenged to improve their interpretation of theology of divine healing. In the light of the experiences of members of Pentecostal churches in Nigeria, Pentecostal churches are now better positioned to proffer new interpretations of this major tenet of theirs. Doing so would reduce if not entirely eliminate the 
intentional and unintentional abuses of the doctrine for the good of humanity at large and add to materials available for the study of the relationship between religion and healing.

\section{Notes and References}

1 C.O. Oshun, "Christ Apostolic Church of Nigeria: A Pentecostal Consideration of its Historical, Theological and Organisational Developments, 1918-1978," Unpublished PhD Dissertation submitted to the University of Exeter, Exeter, 1981.

2 Saibu A. Owoeye, "Prophet E.O. Babalola and Healing Revivalism in Yorubaland," Science in the Perspective of African Religion (AFREL), Islam \& Christianity (ed) S.O. Oyewole et al., Ilorin: Nigerian Association for the Study and Teaching of Religion and the Natural Sciences, 2010, 160-172.

3 O.A. Alokan, "The Place of Revelations and Healings in the Practices of Christ Apostolic Church, Nigeria, 1930-1994," Unpublished PhD Thesis submitted to the Postgraduate College, Obafemi Awolowo University, IleIfe, 2012.

4 B.A. Adedapo, "The Healing Ministry as a Catalyst of the Growth of Christ Apostolic Church in Southwestern Nigeria, 1943-2000," A PhD Dissertation submitted to the Postgraduate College, University of Ibadan, 2014.

5 M.O.A. Oluwaniyi, "Impact of Miracles on Church Growth: A Study of Selected Christ Apostolic Churches in Osun State," an Unpublished DMin. Dissertation submitted to the School of Postgraduate Studies, ECWA Theological Seminary, Igbaja, 2014.

6 Samson O. Akinsulure, "Biblical Leadership Styles: Implications for Christ Apostolic Church's Administration in the South Western States of Nigeria," an Unpublished PhD. Dissertation submitted to the School of Postgraduate Studies, Ahmadu Bello University, Zaria, 2015.

7 Christ Apostolic Church, Christ Apostolic Church Constitution, (Agege: Christ Apostolic Church, 1998), 12.

8 "Tenet," NETBible, n.d., retrieved from http://classic.net.bible.org/lexicon.php?word=tenet, on 22 March 2017, n.p.

9 R.A. Morris, "A Biblical and Theological Analysis of Specific Tenets of Word of Faith Theology: Pastoral Implications for the Church of God," A PhD Dissertation submitted to South African Theological Seminary, Bryanston, South Africa, 26.

10 B.J. Otten, A Manner of the History of Dogmas, (St. Louis, Richmond Heights, 1922).

11 Morris, "A Biblical and Theological Analysis of Specific Tenets of Word of Faith Theology: Pastoral Implications for the Church of God," 33. 
12 G.O. Folarin, "The Origin, Development, and a Brief Appraisal of the Doctrine of the Baptism in the Holy Spirit in Christ Apostolic Church, Nigeria," HTS/Theological Studies, 69(1), Art.\#1333, 2013, n.p.

13 Christ Apostolic Church, Christ Apostolic Church Constitution and Doctrines, (Ibadan: the Supreme Council, Christ Apostolic Church, 1961); Christ Apostolic Church, Christ Apostolic Church Constitution and Doctrines, (Ibadan: Christ Apostolic Church Missionary Headquarters, 1970); Christ Apostolic Church, Christ Apostolic Church Constitution, (Agege: Christ Apostolic Church, 1998).

14 D.O. Babajide, 1980, Iwe Ibeere ati Idahun Ijo C.A.C, (Ilesha: Self Published, 1980), 1.

15 Candy Gunther Brown, "Introduction: Pentecostalism and the Globalization of Illness," in Global Pentecostal and Charismatic Healing (ed) Candy Gunther Brown; (New York: Oxford University Press, 2011), 26. 3-28.

16 Jennifer Anne Cox, "A Re-examination of Faith and Healing in the Gospels: Toward a Pentecostal Theology of Healing and Disability," Cyberjournal for Pentecostal-Charismatic Research, 2017, retrieved from, http://www.pctii.org/cyberj/cyberj24/cox.html, vol. 24, on 10 (September 2017, n.p.).

17 Candy Gunther Brown, "Introduction: Pentecostalism and the Globalization of Illness," 3 .

18 Cox, "A Re-examination of Faith and Healing in the Gospels: Toward a Pentecostal Theology of Healing and Disability," n.p.

19 Vinson Synan, "A Healer in the House?" Hope-Faith-Prayer, n.d., retrieved from, https://www.hopefaithprayer.com/word-of-faith/a-healerin-the-house-vinson-synan/, on 1 August 2017, n.p.

20 Synan, "A Healer in the House?" n.p.

21 Synan, "A Healer in the House?" n.p.

22 A.J. Gordon, The Ministry of Healing, (Grand Rapids: Fleming H. Revell, 1882).

23 "John Alexander Dowie," n.d., retrieved from, http://shawcorp.com/kathy/john_alexander_dowie.htm, on 1 August 2017, n.p.

24 Alexander Dowie, "Doctors, Drugs and Devils, or, the Foes of Christ the Healer, Physical Culture, (April, 1895), 81-86.

25 Synan, "A Healer in the House?" n.p.

26 "Introduction the History and Significance of Early Pentecostal Theology," A Reader in Pentecostal Theology: Voices from the First Generation (ed) Douglas Jacobsen, (Bloomington: Indiana University Press, 2006), 8-9.

27 "The Deadly Various: The Influenza of 1918,"Regional History from the National Archives, retrieved from, https://www.archives.gov/exhibits/influenza-epidemic/, on 2 August 2017. 
28 J.A. Ademakinwa, Christ Apostolic Church: the Faith of Our Fathers, Grand Prairie: Christ Apostolic Church, 1971, 15; cf. J.A. Omoyajowo, Cherubim and Seraphim: The History of an African Independent Church, (Lagos: NOK Publishers, 1982).

29 "Charles Parham," A Reader in Pentecostal Theology: Voices from the First Generation (ed) Douglas Jacobsen, (Bloomington: Indiana University Press, 2006), 31; "William J. Seymour (1817-1922)," A Reader in Pentecostal Theology: Voices from the First Generation (ed) Douglas Jacobsen, (Bloomington: Indiana University Press, 2006), 46-47.

30 "William J. Seymour (1817-1922)," 46-47.

31 R.A.N. Kydd, "Healing in the Christian Church," The New International Dictionary of Pentecostal and Charismatic Movements (ed) S.M. Burgess, E.M. van Maas, (Grand Rapids: Zondervan, 2002), 708.

32 Kydd, "Healing in the Christian Church," 709-710.

33 Kydd, "Healing in the Christian Church," 710.

34 Kydd, "Healing in the Christian Church," 710-711.

35 Kydd, "Healing in the Christian Church," 710.

36 Cox, "A Re-examination of Faith and Healing in the Gospels: Toward a Pentecostal Theology of Healing and Disability;" n.p.; cf. Henry H. Knight, III, "God's Faithfulness and God's Freedom: A Comparison of Contemporary Theologies of Healing," Journal of Pentecostal Theology 1 (1993) 2:66-67, 74-77.

37 S.O. Omidiwura, "African Church Independent Movement," Religious Periscope (1999), 123; cf. A.R. Ogunleye, Elimination by Substitution: Christ Apostolic Church and Indigenous Faith Interplay in Nigeria," European Scientific Journal, 9 (2003), 11:183.

38 "Aladura Churches in Nigeria," Harvard Divinity School Religious Literacy Project, 2017, https://rlp.hds.harvard.edu/faq/aladura-churchesnigeria, 4 August, 2017, n.p.

39 Deji Ayegboyin \& S. Ademola Ishola, African Indigenous Churches (Lagos: Greater Heights Publications, 1977), 67; cf. Adewale Ogunrinde \& Friday Ogbole, "Christianity in Africa: African Indigenous Pentecostal Movements in Nigeria and Ghans," Christianity and African Society: A Festschrift in Honour of Pastor (Dr.) Gabirel Oladele Olutola @80 (ed) Samson A. Fatokun, (Ibadan: BW Bookwright, 2013), 58. Cf. S.A. Fatokun, “'I Will Pour out my Spirit upon all Flesh:' The Origin, Growth and Development of the Precious Stone Church - the Pioneering Indigenous Pentecostal Denomination in Southwest Nigeria," 2010, retrieved from, http://www.pctii.org/cyberj/cyberj19/ fatokun.html \#_ednref14, on 4 August 2017, n.p.

40 J.A. Ademakinwa, Iwe Itan Ijo Aposteli ti Kristi, Nigeria, Agege: CAC Publicity Department, 1971, 15; Ademakinwa, Christ Apostolic Church: the Faith of Our Fathers, Grand Prairie: Christ Apostolic Church, 1971. 
41 J.B. Orogun," "History of CAC," an unpublished lecture delivered at the 5th CAC National Sunday School Conference, Ilorin, 19 June 1982. This appears to be a change from his earlier position presented in J.B. Orogun, Eko Nipa Iwosan Lai Logun, (Ibadan: Loyola Printers, n.d.), 14.

42 Ayegboyin \& Ademola Ishola, African Indigenous Churches, 57; cf. "Aladura Churches in Nigeria," Harvard Divinity School, n.d., retrieved from https://rlp.hds.harvard.edu/faq/aladura-churches-nigeria, on 30 July 2017, n.p.; cf. S.A. Fatokun, “'I Will Pour Out My Spirit Upon All Flesh': The Origin, Growth and Development of the Precious Stone Church - The Pioneering African Indigenous Pentecostal Denomination in Southwest Nigeria," Cyber Journal for Pentecostal-Charismatic Research, 19 (2010), n.p.; Ademakinwa, Christ Apostolic Church: the Faith of Our Fathers, 111.

43 George O. Folarin, Olusegun A. Oladosu \& Stephen Y. Baba, "ReInterpreting the $\tilde{\delta} \delta \omega \rho \zeta \tilde{\omega} v$ ('Living water') Metaphor in John $4 \& 7$ in the Context of the South Western Yoruba in Nigeria," Ilorin Journal of Religious Studies (IJOURELS), 2 (2012), 2:19.

44 Folarin, Oladosu \& Baba, "Re-Interpreting the v̋ $\delta \omega \rho \zeta \tilde{\omega} v$ ('Living water'), 18-20.

45 Adewale O. Ogunrinade, "Predilection for African Indigenous Practices in the Pentecostal Tradition of African Indigenous Churches with reference to Christ Apostolic Church Agbala Itura," Cyberjournal for PentecostalCharismatic Research, No. 18, (2009) retrieved from, http://www.pctii.org/cyberj/cyberj18/adewale.html\#_ednref75, on 7 August 2017, n.p.; cp. D.O. Olayiwola, "Joseph Ayo Babalola 1904-1959 Christ Apostolic Church (Aladura) Nigeria," Dictionary of African Biography, n.d., retrieved from, http://www.dacb.org/stories/nigeria/babalola2_joseph.html, on 15 August 2017, n.p.;

46 Folarin, Oladosu \& Baba, "Re-Interpreting the $\tilde{\delta} \omega \rho \zeta \tilde{\omega} v$ ('Living water'), 19.

47 Ade Alawode, The Lifestyle of a Performer and Reformer- Pastor Abraham Olukunle Akinosun, Ibadan: CAC Publicity Department, 2015, 2016, 25-27; cf. S.G. Adegboyega, Short History of The Apostolic Church in Nigeria, (Ibadan: Rosprint Industrial Press, 1978), 19.

48 Taiye Adamolekun, "A Historical Account of the Advent and Growth of Christ Apostolic Church in Akoko Nigeria," British Journal of Arts and Social Sciences, 8 (2012) 1, retrieved from, http://www.bjournal.co.uk/BJASS.aspx, on 7 August 2017, n.p.

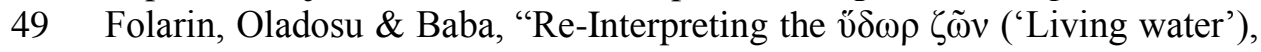
18-20.

50 Ogunrinade, 2009, "Predilection for African Indigenous Practices in the Pentecostal Tradition ...," n.p. 
51 Adeoti Shittu, "5 Prophetic Mountains CAC Founders Established," Nigeria Newspapers, 2016, retrieved from, http://breaking.com.ng/nigeria/5-prophetic-mountains-cac-founderestablished/, on 7 August 2017, n.p.

52 Oluwaniyi, "Impact of Miracles on Church Growth: A Study of Selected Christ Apostolic Churches in Osun State," 2014, 114.

53 Saibu A. Owoeye, "Prophet E.O. Babalola and Healing Revivalism in Yorubaland," Science in the Perspective of African Religion AFRELO, Islam \& Christianity (ed) S.A. Oyewole et al., Ilorin: Local Society Initiative: Nigerian Association for the Study and Teaching of Religion and the Natural Sciences (2010), 164-165.

54 The interactive discussion took place in the Postgraduate Seminar Room of the Department of Religious Studies, Obafemi Awolowo University, IleIfe, on 7 August 2017.

55 Saibu A. Owoeye, "African-Healer Prophets in Selected Independent Churches in Yorubaland, 1963-1998," Unpublished PhD Thesis submitted to the Postgraduate College, (Obafemi Awolowo University, Ile-Ife, 2000), 174.

56 Akinsulure, "Biblical Leadership Styles," 67.

57 The current writer witnessed a church program in a CAC assembly in Modakeke, Ile-Ife, in 2010 when in an early morning service, a revivalist told his audience to slit open their sachet water bags, add salt to the water, and go home and birth with the water. Such a practice is, of course, not condoned by the church but it does happen in situations unknown to the church authorities.

58 Ademakinwa, Christ Apostolic Church: the Faith of Our Fathers, 111.

59 Z.O. Ogunwole, "Healing Practices among African Christians: a Case Study of two Indigenous Churches in Nigeria," Review in Social Sciences 3 (2003), 1\&2:78-79; O.A. Alokan, "The Place of Revelations and Healings," 122.

60 Alokan, "The Place of Revelations and Healings," 115; cf. Ogunwole, "Healing Practices among African Christians," 79, 80

61 See Alokan, "The Place of Revelations and Healings, 1930-1994," 115.

62 Ayegboyin \& Ademola Ishola, African Indigenous Churches, 65-66.

63 Segun Gbadegesin, African Philosophy: Traditional Yoruba Philosophy and Contemporary African Realities, New York: Peter Lang, 1991, 102.

64 J. A. Olanrewaju, "The Biblical Concept of Victory over Evil in the Great Controversy between Good and Evil in Yoruba Contest," Asia-Africa Journal of Mission and Ministry, 3 (2009), 134.

65 Alokan, "The Place of Revelations and Healings," 100.

66 Ayegboyin \& Ishola, African Indigenous Churches, 7.

67 Ayegboyin \& Ademola Ishola, African Indigenous Churches, 66. 
68 Ogunleye, "Elimination by Substitution: Christ Apostolic Church and Indigenous Faith Interplay in Nigeria," European Scientific Journal, 9 (2013), 11:183-184.

69 J.A. Alokan, Christ Apostolic Church @ 90 (1918-2008) (Ile-Ife: Timade Ventures, 2010), 35.

70 Cf. J.W. Williams, "The Transformation of Pentecostal Healing, 19062006," Unpublished PhD, submitted to Florida State University, 2008, 16.

71 Heather Curtis, "Joseph W. Williams, Spirit Cure: A History of Pentecostal Healing," History of Religions, 56, 1(2016), 139-141; cf. Grant Wacker, "The Pentecostal Tradition," in Caring and Curing: Health and Medicine in the Western Religious Traditions, (ed) Ronald L. Numbers \& Darrel W. Amundsen, (New York: MacMillan, 1986), 524-525.

72 Christ Apostolic Church, Christ Apostolic Church (Worldwide) Constitution and Doctrines, (Ibadan: CAC Publicity Department, 1995), 42.

73 See Alokan, "The Place of Revelations and Healings," 101, 118-119.

74 While the KJB, HCSB, and ISV Bibles include, "and fasting" in their translations, NIV, ESB and NASB skip the phrase. The versions with the shorter readings are preferred reading because they come from the oldest available manuscripts. The addition of the phrase, "and fasting" is apparently a redactor's addition.

75 John Odunayo Ojo, The Life and Ministry of Apostle Joseph Ayodele Babalola, Mushin, (Lagos: The Prayer Band Publications, 1988), 26.

76 Shittu, "5 Prophetic Mountains CAC Founders Established," n.p.

77 Ogunrinade, "Predilection for African Indigenous Practices in the Pentecostal Tradition," n.p.

78 Sampson M. Nwaomah, "Anointing with Oil in African Christianity: An Evaluation of Contemporary Practices," Journal of Adventist Mission Studies, 5 (2009), 2:50-64.

79 Christ Apostolic Church General Executive Council, Order of Services of the Christ Apostolic Church (8th edition; Agege: CAC Press, 1994), 75; Eto Isin Gbogbo ti Ijo Apostoli the Kristi Nigeria ati Ghana, 7th ed.; (Agege: CAC Press, 1973), 93.

80 Christ Apostolic Church General Executive Council, Order of Services of the Christ Apostolic Church, 78; cf. Eto Isin Gbogbo ti Ijo Apostoli the Kristi Nigeria ati Ghana, 96.

81 George O. Folarin, "Contemporary State of the Prosperity Gospel in Nigeria," The Asia Journal of Theology 21 (2007), 1:77-78.

82 "Aladura: Nigerian Religion," Encyclopedia Britannica, n.d., retrieved from https://www.britannica.com/topic/Aladura, on 30 July 2017, n.p.

83 Adegboyega, Short History of The Apostolic Church, 6. 
84 David Mekeel, "Understanding the Faith Tabernacle Congregation," 2017, retrieved fromhttp://www.readingeagle.com/news/article/understandingthe-faith-tabernacle-congregation\#.WX3uvOFRFPY, on 30 July 2017, n.p.

85 Olayiwola, "Joseph Ayo Babalola (1904-1959)," Makers of the Church in Nigeria 1842-1947, (ed) J.A. Omoyajowo, Lagos, CSS Bookshop, 1995, 142; cf. Adegboyega, Short History of The Apostolic Church in Nigeria, 124.

86 Orogun, Eko Nipa Iwosan Lai Logun, 13.

87 Adedapo, "The Healing Ministry as a Catalyst of the Growth of Christ Apostolic Church in Southwestern Nigeria, 1943-2000," 101-119.

88 Adedapo, "The Healing Ministry as a Catalyst of the Growth of Christ Apostolic Church in Southwestern Nigeria, 1943-2000,"113.

89 Adedapo, "The Healing Ministry as a Catalyst of the Growth of Christ Apostolic Church in Southwestern Nigeria, 1943-2000,"113.

90 Christ Apostolic Church, Christ Apostolic Church Constitution and Doctrines, Ibadan: The Supreme Council of Christ Apostolic Church, 1968, 42

91 Christ Apostolic Church, Christ Apostolic Church Constitution and Doctrines, 42.

92 G.O. Folarin, "The Organization and Administration of Midwifery in the Christ Apostolic Church (CAC) Maternity Home, Agbokojo, Ibadan (1979-1988)," Unpublished MEd Thesis submitted to the Faculty of Education, (University of Ibadan, 1989), 76-77.

93 Christ Apostolic Church, Christ Apostolic Church Constitution and Doctrines, 52.

94 J.A. Babalola, "Iwosan Lail'ogun," in Leta Mimo Si O, 6.

95 Babalola, "Iwosan Lail'ogun,"in Leta Mimo Si O, 7.

96 Babalola, "Iwosan Lail'ogun,"in Leta Mimo Si O, 9.

97 Ojo, The Life and Ministry of Apostle Joseph Ayodele Babalola, 208.

98 Orogun, Eko Nipa Iwosan Lai Logun, 5.

99 Orogun, Eko Nipa Iwosan Lai Logun, 5.

100 Orogun, Eko Nipa Iwosan Lai Logun, 14.

101 Alokan, "The Place of Revelations and Healings," 101.

102 Adegboyega, Short History of The Apostolic Church in Nigeria, 18-19.

103 Christ Apostolic Church, "The Tenets of CAC," retrieved from http://cacworldwideonline.org/cac_tenets.html, on 10 September, 2017, n.p. 